\title{
Proses Pengembangan Proses Bisnis Transaksi Penjualan pada Toko Erni Karawang
}

\author{
Lila Setiyani $^{1}$, Giofanny Theresia Liswadi ${ }^{2}$, Anwar Maulana $^{3}$ \\ ${ }^{1,2,3}$ Sistem Informasi, STMIK Rosma, Karawang \\ Email: lila.setiyani@dosen.rosma.ac.id
}

\begin{abstract}
Sales transactions are the main element of the current business process at the Erni Karawang Store. In this study, which aims to model the business processes that run at the Erni Store. Modeling is done using Business Process Modeling Notation (BPMN). The method of data collection is done by means of semi-structured interviews which is a method used to answer problems related to referring to a list of open-ended questions, the answers of which are in the form of a narrative sourced from interview activities. Based on the results of data collection, this research produces business process modeling for sales transactions. Modeling can be a tool to identify system requirements as the basis for developing business process management in the business process of sales transactions at the Erni Karawang Store for the better and can increase the effectiveness and efficiency of services. Erni Karawang shop is a shop that sells various goods for people's daily needs. Erni's shop has been around for a long time in the city of karawang and employs two employees to work. However, until now, Toko Erni still uses a manual system and has not used a computerized system. Starting from the process of street transactions, income calculations, price data collection, to inventory data, it is still manually. This makes the quality of the information obtained is not maximal and less efficient, which of course makes the possibility of errors in information and data loss quite large.
\end{abstract}

Keywords: Business Process Modeling Notation (BPMN), Business Process, Sales

\begin{abstract}
Abstrak
Transaksi penjualan merupakan elemen utama mengenai proses bisnis yang berjalan saat ini pada Toko Erni Karawang. Dalam penelitian ini yang bertujuan untuk memodelkan proses bisnis yang berjalan pada Toko Erni. Pemodelan dilakukan dengan menggunakan Business Process Modelling Notation (BPMN). Metode pengumpulan data dilakukan dengan cara wawancara semi terstruktur yang merupakan suatu cara yang digunakan untuk menjawab masalah yang berkaitan dengan mengacu pada daftar pertanyaan terbuka, yang jawabannya berupa narasi yang bersumber hasil dari aktivitas wawancara. Berdasarkan hasil pengumpulan data penelitian ini menghasilkan pemodelan proses bisnis untuk transaksi penjualan. Pemodelan dapat menjadi alat bantu untuk mengidentifikasi kebutuhan sistem sebagai dasar pengembangan business process management dalam proses bisnis transaksi penjualan pada Toko Erni Karawang menjadi lebih baik dan dapat meningkatkan efektivitas dan efisiensi pelayanan. Toko Erni Karawang adalah sebuah toko yang menjual berbagai barang kebutuhan sehari-hari masyarakat. Toko Erni telah berdiri cukup lama di kota karawang dan memperkerjakan dua orang karyawan untuk berkerja. Namun demikian, sampai saat ini Toko Erni masih menggunakan sebuah system secara manual dan belum menggunakan system yang tekomputerisasi. Mulai dari proses transaksi penjalan, perhitunga pendapatan, pendataan harga, hingga data persediaan barang juga masih secara manual. Hal ini membuat kualitas informasi yang didapatkan tidak maksismal dan kurang efisian, dimana tentunya hal ini membuat kemnungkinan terhadinya kesalahan dalam informasi serta kehilangan data yang cukup besar.
\end{abstract}

Kata Kunci: Business Process Modeling Notation (BPMN), Penjualan, Proses Bisnis

\author{
Article History : \\ Received 13, Desember, 2021 \\ Revised 14, Januari, 2022 \\ Accepted 26, Januari, 2022 \\ Corresponding Author: \\ Nama Penulis: Lila Setiyani \\ Departemen: Sistem Infomasi
}

Jurnal Interkom: Jurnal Publikasi Ilmiah Bidang Teknologi Informasi dan Komunikasi

Volume 16 Nomor 04 Bulan Januari - Tahun 2022 


\section{Pendahuluan}

Suatu organisasi pasti memiliki proses bisnis yang mendukung kegiatan bisnis yang ada dalam organisasi untuk mencapai visi dan misi yang teridentifikasi. Proses bisnis itu sendiri adalah serangkaian kegiatan yang bekerja sama dalam lingkungan organisasi dan teknis yang bersama-sama mencapai tujuan bisnis. Jika proses bisnis berjalan baik maka kegiatan operasional akan berjalan lebih efisien dan efektif [1].

Mengelola sistem proses bisnis untuk memperkuat dan meningkatkan manajemen organisasi adalah serangkaian kegiatan perusahaan yang ditempatkan secara khusus yang bergantung pada seperangkat aturan untuk pelaku bisnis atau organisasi. Analisis proses bisnis dilakukan karena diperlukannya suatu evaluasi pada proses bisnis yang ada di organisadi atau usaha tersebut. Sebuah proses yang baik, akan selalu dapat ditingkatkan untuk mencapai proses yang lebih baik [2].

Dalam mengelola sebuah alur proses bisnis, maka konsep yang di pakai adalah business process management seperti yang di kenal kan oleh dumas. Dimana business process management adalah sebuah seni atau ilmu untuk mengawasi cara kerja yang dilakukan organisasi dalam rangka memastikan hasil yang konsisten dan memanfaatkan peluang peningkatan atau perbaikan [2]. Perbaikan sebuah alur proses ini dapat berupa prubahan, pebaikan, ataupun peningkatan sebuah system yang berjalan pada usaha bisnis tersebut. Melakukan sebuah perbaikan dalam sebuah bisnis usaha maka pelaku dari sebuah perbaikan system harus memiliki sebuah inovasi. Dalam hal ini business process management tidak berfokus pada sebuah "perbaikan" namun berfokus pada pengelolaan rantai peristiwa, aktivitas, permasalahan dan keputusan. Untuk mengatasi masalah tersebut peneliti melakukan sebuah analisa permasalah yang ada dan merancang alur proses bisnis sebuah system informasi penjualan yang sesuai dengan Toko Erni. Sistem informasi yang akan dirancang merupakan harapak yang dapat membantu untu perbaikan system informasi yang ada pada Toko Erni hingga mendapatkan informasi yang lebih cepat, jelas dan akurat serta membawa toko erni untuk sedikit lebih maju dalam menghadapi sebuah persaingan teknologi informasi yang berkembenag saat ini.

\section{Tinjauan Pustaka}

\subsection{Penjualan}

Menurut Mulyadi (2008:160) menjelaskan penjualan adalah, "suatu kegiatan yang terdiri dari transaksi penjualan barang atau jasa, secara kredit maupun tunai" [3]. Penjualan adalah suatu aktivitas yang terintegrasi dalam pengembangan berbagai perencanaan strategis yang bertujuan untuk pemenuhan kebutuhan dan kepuasan konsumen yang berakhir pada transaksi penjualan dan memperoleh laba (Ferawati et al., 2020). Penjualan menjadi fokus utama bagi para pengambilan keputusan perusahaan dalam menentukan besarnya target yang harus tercapai di setiap tahunnya. Tujuan dari kegiatan penjualan membantu perusahaan dalam mendapatkan keuntungan dan pendapatan [4]. Menurut Sari dan Nugroho (2017) menjelaskan bahwa penjualan dapat menjamin kelangsungan hidup perusahaan karena laba diperoleh dari hasil penjualan yang mana secara langsung dapat berdampak pada kelangsungan hidup perusahaan.

\subsection{Proses Bisnis}

Proses bisnis merupakan suatu hal yang sudah melekat di berbagai perusahaan atau 
organisasi. Proses bisnis memiliki kegiatan atau kumpulan kegiatan untuk meningkatkan kualitas organisasi atau perusahaan tersebut. Proses bisnis juga diartikan sebagai sebuah jaringan dari kegiatan-kegiatan yang terhubung dengan jelas dan memanfaatkan sumber daya untuk memproses input menjadi output sebagai tujuan untuk memuaskan keinginan pelanggan. Oleh sebab itu, organisasi pasti memiliki proses bisnis atau saling berhubungan erat dengan proses bisnis karena bertujuan untuk meningkatkan kualitas organisasi [5].

Proses bisnis didefinisikan sebagai sekumpulan aktivitas mewujudkan tujuan bisnis mulai dari input, kemudian menambahkan nilai (value added) untuk mendapatkan output berupa hasil yang diinginkan konsumen dengan definisi yang jelas tentang awal proses dan akhir proses [6]. Proses bisnis adalah suatu kumpulan aktivitas atau pekerjaan terstruktur yang saling terkait untuk menyelesaikan suatu masalah tertentu atau yang menghasilkan produk atau layanan [7].

\subsection{Business Process Modeling Notation (BPMN)}

BPMN merupakan diagram yang mengambarkan alur proses bisnis dari suatu sistem atau kegiatan yang direncanakan. Tujuan utama dari BPMN adalah untuk menyediakan suatu notasi dalam pemodelan alur proses bisnis yang mudah dipahami oleh semua pengguna bisnis, mulai dari bisnis analis yang membuat draft dari awal proses, para pengembang teknis yang bertanggung jawab untuk menerapkan teknologi yang akan melakukan proses-proses tersebut, hingga kepada orang-orang bisnis yang akan mengelola dan memantau proses mereka [8].

BPMN dapat digunakan sebagai tools untuk menjelaskan bagaimana cara mendesain sebuah proses bisnis. BPMN juga dapat dikatakan sebagai teknik yang digunakan sebagai alat untuk memungkinkan semua pihak yang terlibat dalam proses bisnis bisa berkomunikasi dengan jelas, benar dan efisien [9].

Business Process Model and Notation merupakan pemodelan proses bisnis menggunakan notasi grafis. BPMN berfungsi untuk menjembatani antara implementasi dan proses bisnisPemodelan proses bisnis dilakukan untuk mengidentifikasi aliran proses bisnis yang disimbolkan degan notas-notasi tertentu. Pendekatan yang paaling mudah untuk mempelajari BPMN adalah mengetahui notasi dasar [10]. Berikut notasi BPMN dapat dilihat pada Tabel 1.

Tabel 2. Notasi Dasar BPMN

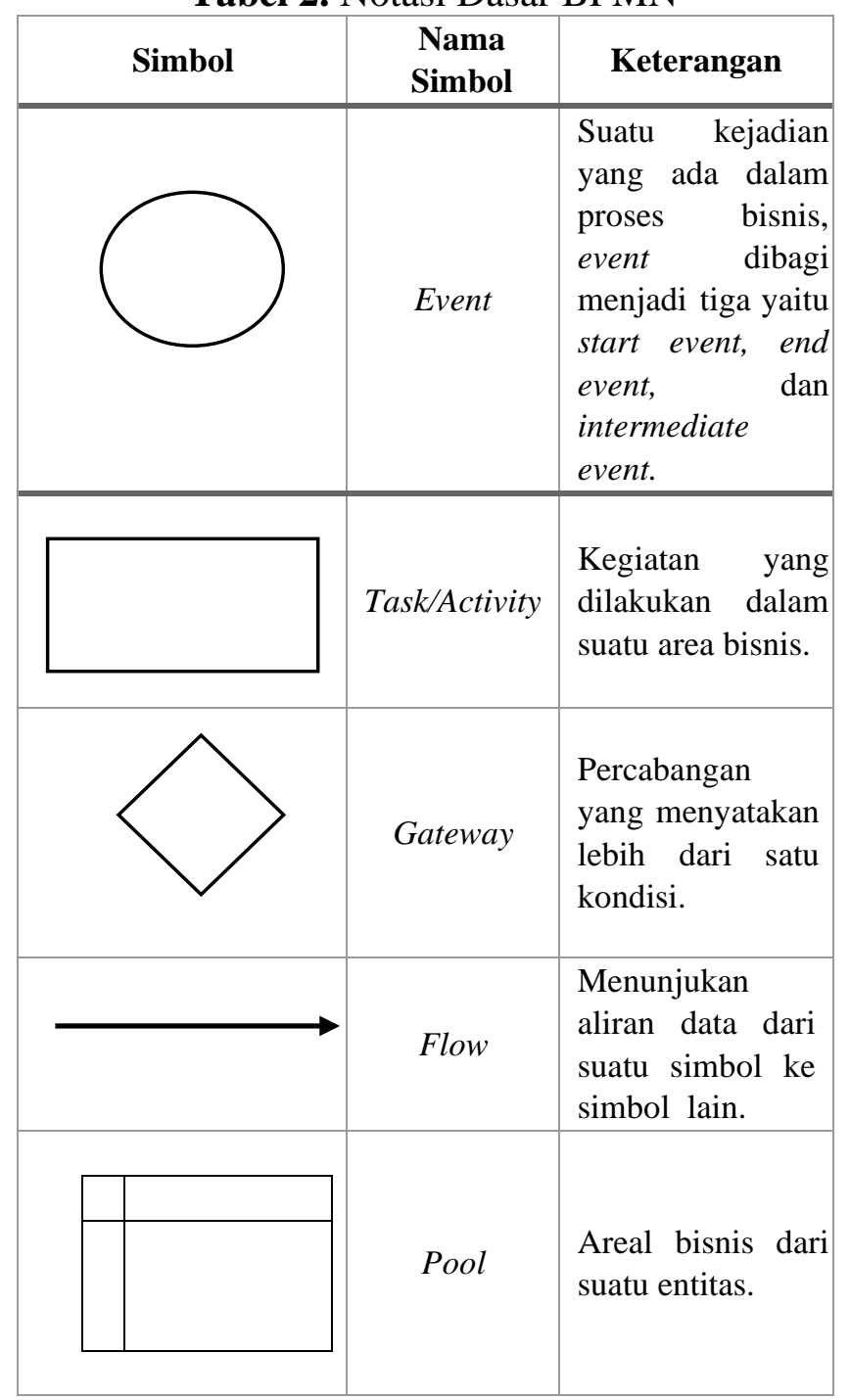




\section{Metode Penelitian}

Dalam penelitian ini, pengumpulan data dilakukan dengan cara kualitatif yang merupakan suatu yang digunakan untuk menjawab masalah yang berkaitan dengan data yang berupa narasi yang bersumber hasil dari aktivitas wawancara. Wawancara yang dilakukan menggunakan jenis wawancara semi terstruktur dengan mengacu pada daftar pertanyaan terbuka. Responden di pilih menggunakan teknik non propability sampling dimana pemilik Toko Erni Karawang yang menangani seluruh proses transaksi penjualan. Prosedur dari penelitian ini dimulai dengan pengumpulan data, analisis dan pemodelan proses bisnis menggunakan BPMN dengan tool Bizagi Modeler. Berikut adalah pertanyaan yang di ajukan pada wawancara :

Tabel 2. Pertanyaan Wawancara

\begin{tabular}{|c|l|}
\hline No. & \multicolumn{1}{|c|}{ Pertanyaan } \\
\hline 1 & Bagaimana alur proses transaksi Penjualan yang saat ini terjadi ? \\
\hline 2 & Siapa saja yang terlibat dalam proses transaksi penjualan ? \\
\hline 3 & Permasalahan-permasalahan apa yang dihadapi saat proses transaksi penjualan terjadi? \\
\hline 4 & Harapan-harapan kedepan pemilik toko? \\
\hline 5 & Dokumen-dokumen apa saja yang terlibat pada proses transaksi penjualan yang terjadi? \\
\hline
\end{tabular}

\section{Hasil dan Pembahasan}

Berdasarkan pengumpulan data yang telah dilakukan, maka didapatkan data sebagai berikut :

\section{a. Alur Proses Bisnis Saat Ini}

Didalam toko tersebut ada pemilik toko yang berperan langsung sebagai kasir, dan pegawai toko yang diperkerjakan untuk membereskan barang, mengecek ketersediaan barang, serta mengirimkan barang kepada pembeli, saat ini sistematis pembelian ditoko tersebut masih manual. Pembeli menitipkan kertas berisikan list pesanan yang ingin dibeli, yang kemudian diterima kasir dan diberikan kepada pegawai nya untuk dicek ketersediaan barang yang dipesan pembeli, jika semua barang dalam list pesanan tersebut tersedia maka pegawai toko langsung mempacking pesanan. Tetapi jika ada barang yang dipesan ternyata kosong maka kasir akan menghubungi pembeli untuk mengkonfirmasi bahwa ada barang yang kosong dan menanyakan barang pengganti yang diingikan yang kemudian akan dicek kembali apakah barang pengganti yang diingikan tersedia sampai barang pengganti yang diinginkan tersedia dan semua pesanan komplit maka barang pesanan akan dipacking, sedangkan jika semua pilihan barang pengganti yang diinginkan pembeli kosong, pembeli dapat membatalkan pesanannya, saat pesanan complete dan sudah dipacking, kasir akan membuat nota tertulis secara manual, kemudian diberikan kepada pegawai toko untuk mendapatkan alamat pembeli dan mengirimkannya kepada pembeli serta menerima uang pembayarannya.

\section{b. Aktor yang terlibat}

Aktor yang terlibat pada transaksi penjualan adalah pemilik toko sebaga kasir, pegawai toko, dan pembeli.

\section{c. Permasalahan yang ada}

Berikut ermasalahan-permasalahan yang dihadapi oleh user.

Data stock barang yang tersedia dan pengecekan ketersediaan barang yang masih manual dimana dapat memakan waktu yang lama. 
Penghitungan total belanjaan yang masih menggunakan kalkulator dan pencatatan yang masih manual dinama memungkinkan kesalahan perhitungan total belanjaan serta dapat terjadi kesalahan pencatatan

\section{d. Harapan-harapan user}

Berikut merupakan harapan user terkait dengan peningkatan sistem yang berjalan.

1) User berharap kegiatan proses transaksi bisa berjalan lebih efektif dan efisien.

2) Meningkatkan pelayanan.

3) Memudahkan user dalam pembuatan laporan.

\section{e. Dokumen yang terlibat}

Dokumen-dokumen yang terlibat dalam proses bisnis berjalan.

1) List pesanan

2) Nota

Berdasarkan hasil wawancara yang dilakukan untuk pengumpulan data dan setelah di lakukan identifikasi pada transaksi penjualan, maka dilakukan pemodelan proses transaksi penjualan menggunakan BPMN dengan tool Bizagi Modeler :

\section{a. Pemodelan Proses Transaksi Penjualan}

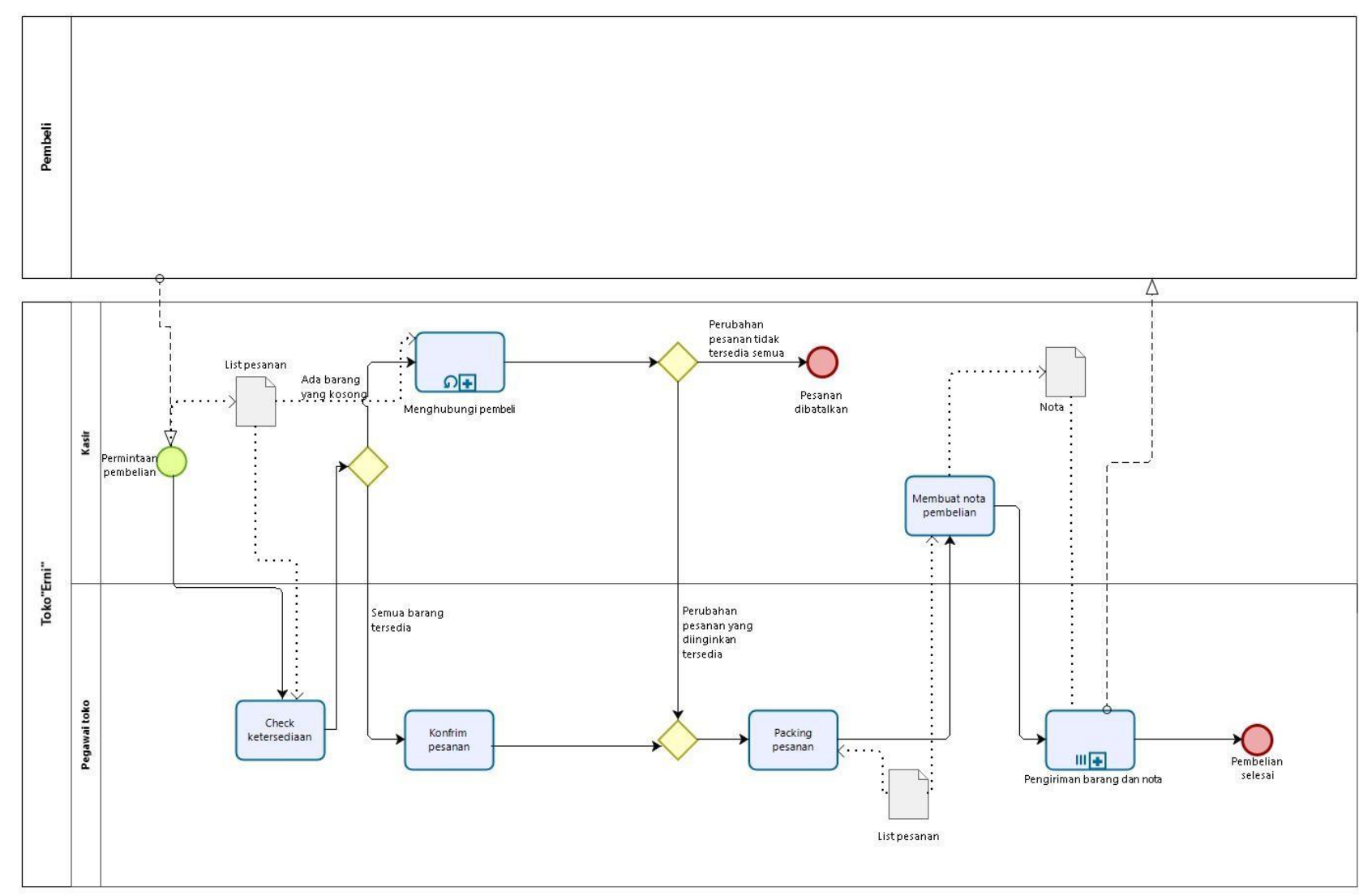

Gambar 1. Proses Bisnis Penjualan

\section{b. Sub-process repetition "menghubungi pembeli”}




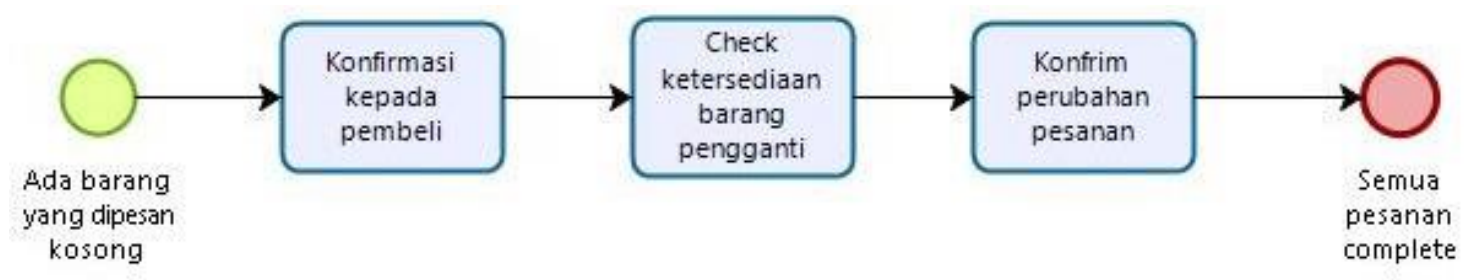

Gambar 2. Sub Proses Perulangan

\section{c. Sub-process paralel "Pengiriman barang} dan nota"

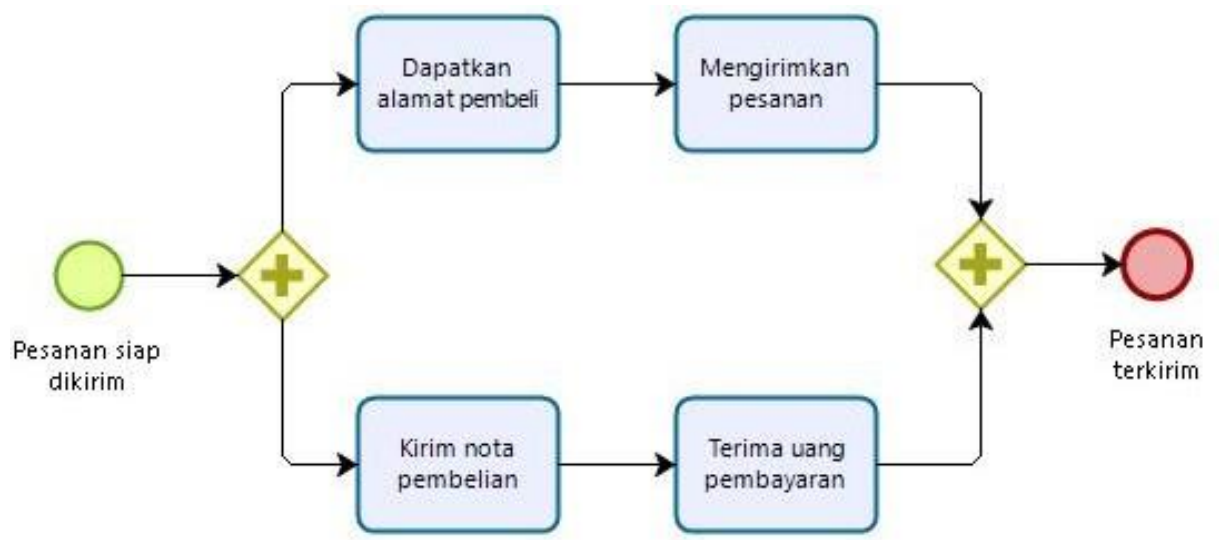

Gambar 3. Sub Proses pararel

Pemodelan proses bisnis yang berjalan saat ini berdasarkan pada informasi yang telah dikumpulkan dari narasumber pegawai toko dan pemilik toko dari Toko Erni Karawang yang menangani proses transaksi penjualan.

\section{Kesimpulan}

Transaksi penjualan merupakan elemen utama mengenai proses bisnis yang berjalan saat ini pada Toko Erni Karawang. Proses pemodelan bisnis yang berjalan saat ini dapat terus dikembangkan agar kinerja penjualan secara keseluruhan dan kepuasan terhadap pelaku atau aktor yang terlibat pada penjualan dapat meningkat. pemodelan analisa proses bisnis dengan mengidentifikasi proses dan sub proses pada transaksi penjualan dalam bentuk BPMN. Hasil pemodelan dapat menjadi alat bantu untuk mengidentifikasi kebutuhan sistem sebagai dasar pengembangan business process management dalam proses bisnis transaksi penjualan pada Toko Erni Karawang menjadi lebih baik dan dapat meningkatkan efektivitas dan efisiensi pelayanan.

\section{Saran}

Pada penelitian ini hanya terbatas pada pemodelan BPMN saja. Untuk penulis selanjutnya diharapkan dapat mengembangkan penelitian ini dengan membuat sistem mengenai transaksi penjualan sesuai dengan proses bisnis yang dibuat dalam penelitian ini.

\section{Daftar Pustaka}

[1] L. Setiyani and B. Setiawan, "Analisis Dan Design Manajemen 
Control Produksi Menggunakan Business Process Improvement Dan Unified Modelling Language (Studi Kasus: Pt. Multistrada)," J. Interkom J. Publ. Ilm. Bid. Teknol. Inf. dan Komun., vol. 16, no. 1, pp. 27-37, 2021, doi: 10.35969/interkom.v16i1.132.

[2] L. Setiyani, "Process Discovery Pada Transaksi Penjualan Cv. Jatayu Catra Internusa," J. Simasi J. Ilm. Sist. Inf., vol. 1, no. 1, pp. 14-19, 2021.

[3] F. Kamal and R. Ruliyan, "Pengelolaan Pajak Pertambahan Nilai Pada Transaksi Penjualan (Studi Kasus: PT Elsiscom Prima Karya Jakarta)," JMBI UNSRAT (Jurnal Ilm. Manaj. Bisnis dan Inov. Univ. Sam Ratulangi)., vol. 6, no. 1, pp. 51-60, 2019 , doi: 10.35794/jmbi.v6i1.24274.

[4] C. W. Oktavia, C. Natalia, F. Suprata, and A. Hindratmo, "Analisis dan Implementasi Simulasi Monte Carlo untuk Prediksi Kebutuhan Gula berdasarkan Penjualan Bumbu Tabur XYZ," J. METRIS, vol. 21, no. 02, pp. 103-110, 2020, doi: 10.25170/metris.v21i02.2494.

[5] V. Velayati, D. Wardani, R. A. Nadhifah, and M. A. Yaqin, "Pengukuran Kematangan Proses Bisnis Pada Organisasi Sekolah Menggunakan Business Process Maturity Model (BPMM)," Ilk. J. Comput. Sci. Appl. Informatics, vol. 2, no. 3, pp. 329-348, 2020, doi: 10.28926/ilkomnika.v2i3.157.

[6] A. Hodijah, "Penerapan Business Process Management Pada Arsitektur Sistem Berorientasi Service ( Soa )," J. TEDC, vol. 8, no. 1, pp. 74-79, 2014.

[7] Y. Saepulloh, D. Rosadi, and A. Riswaya Ririh, "Sistem Pelaporan Kunjungan Debt Collector Kartu Kredit," J. Comput. Bisnis, vol. 15, no. 1, pp. 1-6, 2021.
[8] Herdiyanto, "Notulis - Aplikasi Minute of Meeting Pada Modul Admin \& Pengelola Rapat," Fak. Ilmu Terap. Telkom Univ., vol. 6, no. 2, pp. 1-8, 2020.

[9] A. R. Perdanakusuma, A. Rachmadi, M. G. Muhammad, D. R. Ramadhan, and I. M. Ubaidillah, "Pemodelan Proses Bisnis Pelayanan Aduan Publik pada Dinas Komunikasi dan Informatika Kabupaten Mojokerto dengan Menggunakan Business Process Model Notation ( BPMN ) Dinas Komunikasi dan Informatika Kabupaten Mojokerto menyediakan dan melayani aduan publik," $J$. Technoscienza, vol. 5, no. 1, pp. 137156, 2020.

[10] D. S. A. Prasetya, R. Budiawan, and Suryatiningsih, "Aplikasi Administasi Penghitungan Pelanggaran Siswa di Sekolah," $e$ Proceeding Appl. Sci., vol. 5, no. 1, pp. 98-107, 2019. 